\title{
CORROSION INHIBITION EFFICIENCY OF HUMAN BLACK HAIR SAMPLE FOR MILD STEEL IN PHOSPHORIC ACID
}

\author{
T. Sathiyapriya ${ }^{1, *}$ and G. Rathika ${ }^{2}$ \\ ${ }^{1}$ Department of Chemistry, SVS College of Engineering, \\ Coimbatore-642 109. Tamil Nadu, India. \\ ${ }^{2}$ Department of Chemistry, PSG College of Arts and Science, \\ Coimbatore-641 014. Tamil Nadu, India. \\ *E-mail:sathiyachallenge87@gmail.com
}

\begin{abstract}
This present research work studied the use of human ethnic hair sample extract as corrosion inhibitors of mild steel (MS) in $1 \mathrm{M} \mathrm{H}_{3} \mathrm{PO}_{4}$ medium by mass loss, Potentiodynamic polarization, Electrochemical Impedance Spectroscopy. The results showed that the corrosion inhibition efficiency increased with increasing the concentration of the inhibitor. The extract was a mixed type inhibitor with an optimum concentration of $0.040 \% \mathrm{v} / \mathrm{v}$ in potentiodynamic polarization. The adsorption characteristics of the inhibitors have been determined from the results. Scanning electron microscopy (SEM) study revealed that the inhibition of corrosion of mild steel by adsorption of the inhibitor molecules on the mild steel surface.
\end{abstract}

Keywords: Mild steel, Corrosion inhibition, Human hair extract, Electrochemical techniques, SEM analysis.

\section{INTRODUCTION}

Mild steel is a material which is broadly used in engineering and others because of its low price and easy availability for various reaction vessels, tanks, pipes and automobile applications etc. During industrial procedures such as acid pickling, etching, acid cleaning and acid descaling, mild steel is frequently made to come in contact with violent acid solutions and get corroded. Corrosion is a serious problem and industries spend a huge amount of finance to overcome it.

Use of inhibitors is the finest way to prevent degradation of metal surfaces in acid media. These inhibitors are substances which may be either prepared in the laboratory or natural compounds, added in minor quantities to the acidic medium, to reduce the rate of deterioration. Numerous synthetic compounds are reported by researchers as corrosion inhibitors for metals in acid medium. Though the synthetic inhibitors reduce corrosion, the use of such inhibitors is gradually banned by strict environmental regulations because of their toxic nature and difficulties at their disposal. This has made the scientists to cultivate a new range of corrosion inhibitors which are less toxic, eco-friendly, biodegradable with good efficiency. Up to now, a number of natural products like plant extracts, amino acids, proteins, and biopolymers have been successfully reported to be corrosion inhibitor. ${ }^{1-3}$

The present work continues on focusing the application of a biowaste (Human hair) as a corrosion inhibitor on mild steel in $1 \mathrm{M} \mathrm{H}_{3} \mathrm{PO}_{4}$. Human hair is the one which is considered unusable in most peoples and therefore is found in the municipal waste in almost all cities.

Human hair is composed of proteins, lipids, water, trace elements and pigments, which is considered as a useless pollutant in our society. It is a biodegradable material but takes more time even years and during its decomposition, it leaves nitrogen, sulfur and so on. The burning of hair sample also produces a foul smell and also toxic gases. Open dump of hair produces dust which causes discomfort to people living around it. Sweat and other organic matter sticking over the hair sample liberates bad odor to the atmosphere. Interestingly certain high-quality hair is traded all over the world for making fertilizers, artwork, Wigs, Hair Extensions, Eyelashes, Moustaches, Beards and Other Beauty Accessories etc. But one thing all have to 
agree that not all the human hair is marketed, only high-quality long hair is imported remaining local barber shop hairs and others are dumped in the waste streams which causes a severe pollution problem. Hence, the best way to solve the problem is to find wealth out of waste.

From the literature, it is known that human hair is made up of proteins which is the condensation polymers of amino acids. The amino acids that are found in human hair sample are represented in Table-1:

Table 1. List of amino acids present in the human hair sample. ${ }^{4-6}$

\begin{tabular}{c|l|c|l}
\hline S. No. & Name of the Amino acid & S. No. & Name of the Amino acid \\
\hline 1. & Glycine & 12. & Citrulline \\
\hline 2. & Alanine & 13. & Aspartic acid \\
\hline 3. & Valine & 14. & Glutamic acid \\
\hline 4. & Isoleucine & 15. & Threonine \\
\hline 5. & Leucine & 16. & Serine \\
\hline 6. & Phenylalanine & 17. & Cystine \\
\hline 7. & Tyrosine & 18. & Methionien \\
\hline 8. & Lysine & 19. & Cysteine \\
\hline 9. & Arginine & 20. & Cysteic acid \\
\hline 10. & Ornithine & 21. & Proline \\
\hline 11. & Histidine & 22. & Tryptophan \\
\hline
\end{tabular}

It is reported in numerous scholarly articles that compounds containing heteroatoms such as nitrogen, oxygen, and Sulphur and multiple bonds behave as good corrosion inhibitors. Since the $\pi$-electrons present in the inhibitor interacts with the surface of the metal. ${ }^{7}$ Meanwhile amino acids act as a good corrosion inhibitor, because of the presence of nitrogen, oxygen and multiple bonds.

Hence in the current research work, a human hair sample is tested to act as a corrosion inhibitor for mild steel in $1 \mathrm{M} \mathrm{H}_{2} \mathrm{SO}_{4}$.

\section{Preparation of Specimens}

\section{EXPERIMENTAL}

Mild steel specimens containing $0.09 \% \mathrm{P}, 0.37 \% \mathrm{Si}, 0.01 \% \mathrm{Al}, 0.05 \% \mathrm{Mn}, 0.19 \% \mathrm{C}, 0.06 \% \mathrm{~S}$ and the remainder Fe were polished with four-grade emery papers, degreased with acetone and stored in a desiccator and used.

\section{Preparation of extract}

Human black hair of ethnic nature was cut into small pieces, washed with double distilled water, then with ethanol and dried well. $10 \mathrm{~g}$ of water hair sample is digested in $10 \mathrm{ml}$ of $1 \mathrm{M} \mathrm{NaOH}$ at $70-90^{\circ} \mathrm{C}$. And it is made up to $500 \mathrm{ml}$ using double distilled water.

\section{Weight loss Measurements}

Mass loss measurements were done on mild steel specimens in $1 \mathrm{M} \mathrm{H}_{3} \mathrm{PO}_{4}$ solution with and without of inhibitors. Initial weights of the polished mild steel specimens were noted. The sample was immersed using glass hooks in triplicate in the $1 \mathrm{M} \mathrm{H}_{3} \mathrm{PO}_{4}$ solution contained in a $100 \mathrm{ml}$ beaker, both in the absence and presence of inhibitor for different intervals of time (Table 2 and 3). The specimens were taken out, washed with distilled water, dried and reweighed. The corrosion rate (CR) and inhibition efficiency (IE \%) was calculated using the formula (1) and (2) respectively.

Corrosion rate $=\frac{87.6 \times \mathrm{W}}{\mathrm{D} \mathrm{A} \mathrm{T}}$

$W$ is weight loss in $\mathrm{mg}, D$ is density in $\mathrm{mg}, A$ is area of exposure in $\mathrm{cm}^{2}$, and $T$ is time in hours.

IE $(\%)=\frac{\text { Wo-Wt }}{\text { Wo }}$

$W_{0}$ is weight loss without inhibitor. $W_{t}$ is weight loss with inhibitor. The effects of temperature on the corrosion inhibition performance for the various concentrations of the human hair extract were studied in 
RASĀYAN J. Chem.

Vol. 10 | No. 4 |1462-1471 | October - December | 2017

the range of (303 to $323 \mathrm{~K}$ ). The solution temperature was thermostatically controlled at desired temperatures.

\section{Electrochemical Measurements}

Electrochemical studies were carried out by using an electrochemical workstation, Bio-logic SP 200 instrument. A three-electrode compartment cell was used for the electrochemical measurements. A saturated calomel electrode (SCE) and a platinum electrode were used as the reference and the mild steel as the working electrode (WE), respectively. The area of the WE exposed to the solution was approximately $1 \mathrm{~cm}^{2}$. The specimen was pretreated similarly as done in the gravimetric measurements. Before each potentiodynamic polarization and electrochemical impedance spectroscopy studies, the electrode was allowed to corrode freely and its open circuit potential (OCP) was recorded as a function of time up to 20 min, which was sufficient to attain a stable state. The polarization measurements were carried out from a potential range of $-200 \mathrm{mV}$ to $+200 \mathrm{mV}$ with respect to open circuit potential in absence and presence of inhibitor at a scan rate of $1 \mathrm{mV} / \mathrm{sec}$. Electrode potentials were measured with respect to SCE. The polarization studies were done immediately after the EIS studies on the same electrode without any further surface treatment. The AC impedance was performed in the frequency range from $20 \mathrm{kHz}$ to $200 \mathrm{~Hz}$ with a single amplitude of $10 \mathrm{mV}$. Fresh solution and fresh mild steel samples were used after each sweep.

\section{Surface Analysis}

The surface morphology of mild steel specimen immersed in $1 \mathrm{M} \mathrm{H}_{3} \mathrm{PO}_{4}$ in the absence and presence of hair sample extract at room temperature for $2 \mathrm{hr}$ was studied using a Scanning Electron Microscope (SEM).

\section{Weight loss measurement}

\section{RESULTS AND DISCUSSION}

Weight loss measurements of mild steel specimen in $1 \mathrm{M} \mathrm{H}_{3} \mathrm{PO}_{4}$ without and with different concentrations of hair extract was carried out for $1 \mathrm{hr}, 3 \mathrm{hr}, 5 \mathrm{hr}, 7 \mathrm{hr}$ and $24 \mathrm{hr}$ immersion period and temperatures of $303 \mathrm{~K}$ to $333 \mathrm{~K}$. Inhibitor efficiency (I.E \%) and corrosion rate (CR) was calculated and exhibited in table 2 and 3. It was noted from the data from Table-2 that the I.E. (\%) increases with increases in inhibitor concentration. Optimum inhibition efficiency of $98.57 \%$ was obtained at $0.04 \% \mathrm{v} / \mathrm{v}$ hair sample extract concentration at room temperature for $5 \mathrm{hr}$ immersion. It is further noted from the data that corrosion rate decreases on increasing the inhibitor concentration for all the immersion periods at room temperature. From the Table-3, it is clear that corrosion rate of mild steel in $1 \mathrm{M} \mathrm{H}_{3} \mathrm{PO}_{4}$ increases with increase in temperature for both the absence and presence of inhibitor. It is noted from the data that the inhibition efficiency increases with increasing temperature till $323 \mathrm{~K}$ and after that, the I.E (\%) decreases. I.E. (\%) of $94.74 \%$ was obtained at $313 \mathrm{~K}$ with $0.040 \% \mathrm{v} / \mathrm{v}$ inhibitor concentration. It may be because of desorption of the inhibitor from the mild steel surface on increasing in temperatures the inhibition efficiency decreases.

Table-2: CR (mpy) and IE (\%) of Black hair extract in 1M Phosphoric acid at different concentrations and different immersion periods.

\begin{tabular}{c|c|c|c|c|c|c|c|c|c|c|c}
\hline \multirow{2}{*}{ S. No. } & \multirow{2}{*}{$\begin{array}{c}\text { Conc. } \\
(\mathrm{v} / \mathrm{v} \%)\end{array}$} & \multicolumn{2}{|c|}{$1 \mathrm{hr}$} & \multicolumn{2}{c|}{$3 \mathrm{hr}$} & \multicolumn{2}{c|}{$5 \mathrm{hr}$} & \multicolumn{2}{c|}{$7 \mathrm{hr}$} & \multicolumn{2}{c}{$24 \mathrm{hr}$} \\
\cline { 3 - 13 } & & $\mathrm{CR}$ & $\mathrm{IE}(\%)$ & $\begin{array}{c}\mathrm{CR} \\
(\mathrm{mpy})\end{array}$ & IE (\%) & $\begin{array}{c}\mathrm{CR} \\
(\mathrm{mpy})\end{array}$ & IE (\%) & $\begin{array}{c}\mathrm{CR} \\
(\mathrm{mpy})\end{array}$ & IE (\%) & $\begin{array}{c}\mathrm{CR} \\
(\mathrm{mpy})\end{array}$ & IE (\%) \\
\hline 1. & Blank & 0.4604 & $* *$ & 0.3070 & $* *$ & 0.3223 & $* *$ & 0.3157 & $* *$ & 0.2868 & $* *$ \\
\hline 2. & 0.006 & 0.1381 & 70.000 & 0.0460 & 85.000 & 0.0322 & 90.000 & 0.0296 & 90.625 & 0.0671 & 76.589 \\
\hline 3. & 0.012 & 0.1151 & 75.000 & 0.0307 & 90.000 & 0.0230 & 92.857 & 0.0197 & 93.750 & 0.0547 & 80.936 \\
\hline 4. & 0.018 & 0.0921 & 80.000 & 0.0230 & 92.500 & 0.0184 & 94.286 & 0.0164 & 94.792 & 0.0384 & 86.622 \\
\hline 5. & 0.024 & 0.0691 & 85.000 & 0.0153 & 95.000 & 0.0138 & 95.714 & 0.0132 & 95.833 & 0.0355 & 87.625 \\
\hline 6. & 0.030 & 0.0460 & 90.000 & 0.0153 & 95.000 & 0.0092 & 97.143 & 0.0099 & 96.875 & 0.0345 & 87.960 \\
\hline 7. & 0.040 & 0.0460 & 90.000 & 0.0077 & 97.500 & 0.0046 & 98.571 & 0.0099 & 96.875 & 0.0297 & 89.632 \\
\hline
\end{tabular}


RASĀYAN J. Chem.

Vol. 10 | No. 4 |1462-1471 | October - December | 2017

Table-3: CR and IE (\%) of Black sample extract in $1 \mathrm{M}$ Phosphoric acid at different concentrations and different temperatures

\begin{tabular}{c|c|c|c|c|c|c|c|c|c}
\hline \multirow{2}{*}{ S. No. } & Conc. & \multicolumn{2}{|c|}{$303 \mathrm{~K}$} & \multicolumn{2}{c|}{$313 \mathrm{~K}$} & \multicolumn{2}{c|}{$323 \mathrm{~K}$} & \multicolumn{2}{c}{$333 \mathrm{~K}$} \\
\cline { 3 - 10 } & $(\mathrm{v} / \mathrm{v} \%)$ & $\mathrm{CR}$ & IE\% & CR & IE\% & CR & IE\% & CR & IE\% \\
\hline 1. & Blank & 0.4604 & $* *$ & 0.8748 & $* *$ & 1.7267 & $* *$ & 2.8778 & $* *$ \\
\hline 2. & 0.006 & 0.1381 & 70.000 & 0.1381 & 84.211 & 0.1842 & 89.333 & 1.0360 & 64.57 \\
\hline 3. & 0.018 & 0.0921 & 80.000 & 0.0921 & 89.474 & 0.1151 & 93.333 & 0.8748 & 70.08 \\
\hline 4. & 0.030 & 0.0460 & 90.000 & 0.0691 & 92.105 & 0.0921 & 94.667 & 0.6907 & 76.38 \\
\hline 5. & 0.040 & 0.0460 & 90.000 & 0.0460 & 94.737 & 0.0921 & 94.667 & 0.6216 & 78.74 \\
\hline
\end{tabular}

\section{Adsorption isotherm}

Adsorption isotherms explain the mode and degree of interface between the surface of the mild steel and inhibitor molecules. Surface coverage and the inhibitor concentration were used to obtain the isotherms. A number of attempts were made to find the best fit and it is seen that the adsorption of the inhibitor molecules on the mild steel specimen follows both Langmuir and Temkin adsorption isotherm. ${ }^{8}$

Langmuir adsorption equation is given by,

$\frac{\mathrm{C}}{\Theta}=\frac{1}{\mathrm{~K}_{\mathrm{ads}}}+\mathrm{C}$

Where $\Theta$ is the surface coverage, $K_{a d s}$ is adsorption equilibrium constant, $C$ is the inhibitor concentration. Langmuir isotherm is an isotherm confirms the formation of a multimolecular layer of adsorption of the inhibitor and it suggested the absence of interaction among the adsorbate and the adsorbent. ${ }^{9}$ Straight line graphs were got by plotting values of $\log \Theta / 1-\Theta$ vs. $\log C$ is shown in Fig.-1.

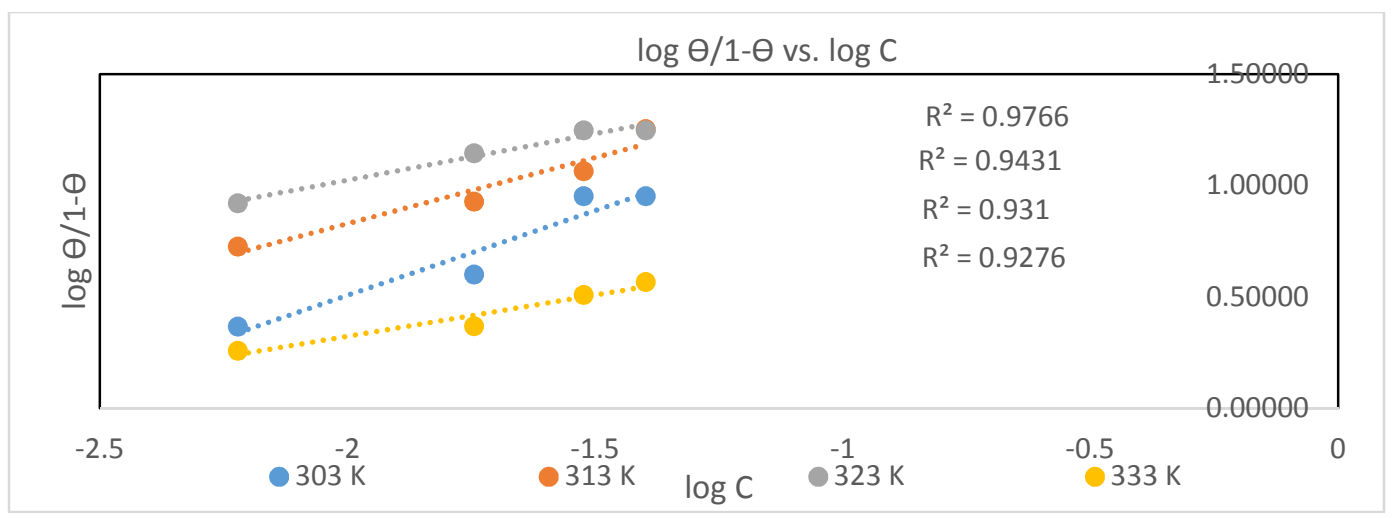

Fig.-1: Langmuir Adsorption Isotherm

Temkin adsorption isotherm equation is given by,

$\log \theta / \mathrm{C}=\log \mathrm{K}-\mathrm{g} \theta$

Where, $\mathrm{C}$ is the concentration of the inhibitor

$\mathrm{K}$ adsorptive equilibrium constant

$\theta$ is the surface coverage

$\mathrm{G}$ is the adsorbate parameter

The plot of $\log \mathrm{C}$ against $\theta$ yields lines as shown in Fig.-2. It is evident that the $\mathrm{R}^{2}$ value is almost equal to 1 which indicates the adsorption of the inhibitor on mild steel obeys Temkin adsorption isotherm. It also illustrates the chemical adsorption of uncharge molecules on the metal surface. The experimental data fit 
both Langmuir and Temkin adsorption isotherm which supports the mixed inhibition mechanism suggested by electrochemical measurements. This type of behavior is attributed to the formation of multilayer physical adsorption on the monolayer of chemical adsorption. ${ }^{10}$

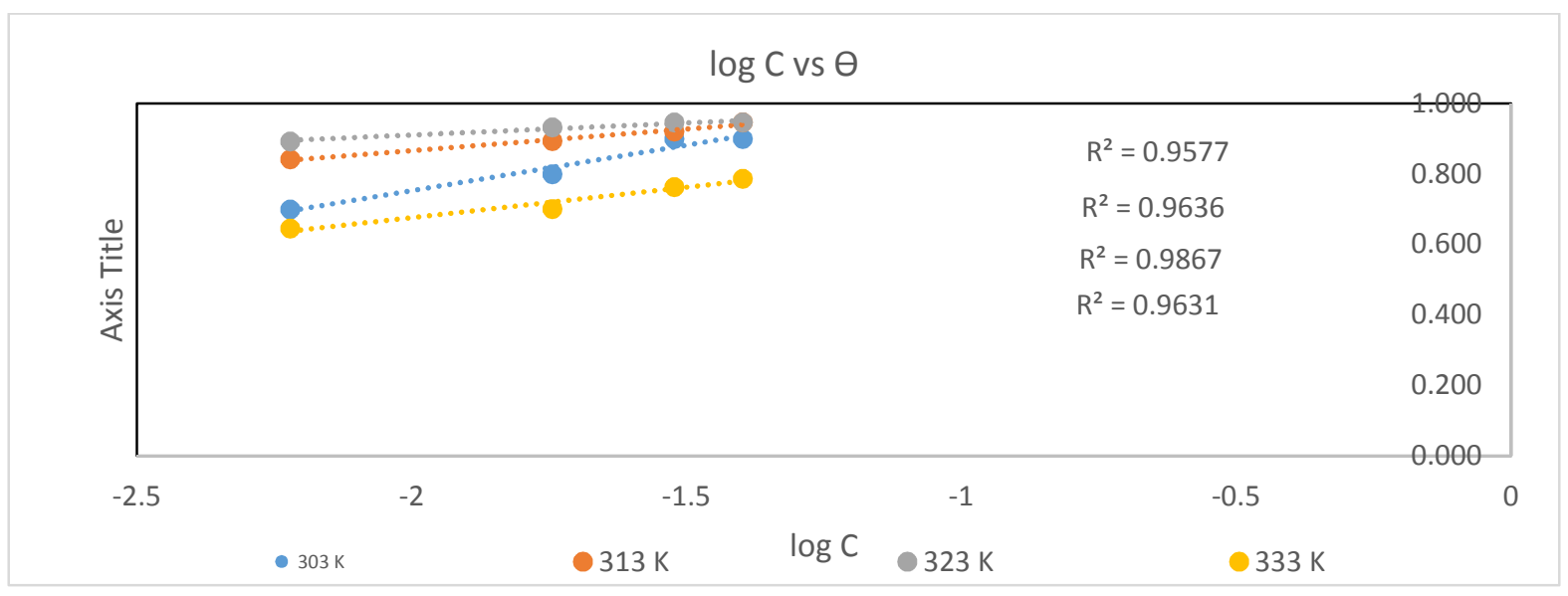

\section{Adsorption parameters}

Fig.-2: Temkin Adsorption Isotherm

The activation energy for the corrosion reaction of mild steel in the phosphoric acid medium in the absence and presence of different concentrations of human black hair extract is given in Table-3. Arrhenius plot (Fig.-3) of $\log (\mathrm{CR} / \mathrm{T})$ versus $1 / \mathrm{T}$ for the corrosion of mild steel in the absence and presence of inhibitors in $1 \mathrm{M} \mathrm{H}_{3} \mathrm{PO}_{4}$ was given in Fig.-5. Activation energy $\left(\mathrm{E}_{\mathrm{a}}\right)$ was calculated using Arrhenius equation,

$$
\text { Icorr }=\mathrm{A} \exp \left(\frac{-\mathrm{Ea}}{\mathrm{RT}}\right)
$$

Where $\mathrm{I}_{\text {corr }}$ is the reaction rate, $\mathrm{A}$ is a constant, $\mathrm{E}_{\mathrm{a}}$ the activation energy of the reaction, $\mathrm{T}$ absolute temperature and $\mathrm{R}$ is the universal gas constant. These $\mathrm{E}_{\mathrm{a}}$ values (Table-3) ranged from $51.87-70.27 \mathrm{KJ} / \mathrm{mol}$ supporting the mechanism of physical adsorption. For a physical adsorption, it is expected that the value of $\mathrm{E}_{\mathrm{a}}$ should be less than $80.00 \mathrm{KJ} / \mathrm{mol} .^{11-13}$

Activation parameters like $\Delta \mathrm{H}_{\text {ads }}$ and $\Delta \mathrm{S}_{\text {ads }}$ for the corrosion reaction, transition state plot was used.

$\mathrm{CR}=\frac{\mathrm{RT}}{\mathrm{Nh}} \exp \frac{\Delta \mathrm{Sads}}{\mathrm{R}} \exp \frac{-\Delta \mathrm{Hads}}{\mathrm{RT}}$

Where $h$ is Planck's constant, $N$ is Avogadro's number, $R$ is the universal gas constant, $T$ is the absolute temperature, $\Delta S$ is the entropy of activation, and $\Delta H$ is the enthalpy of activation.

Table-4: Activation parameters of $1 \mathrm{M} \mathrm{H}_{3} \mathrm{PO}_{4}$ on mild steel for different temperatures.

\begin{tabular}{c|c|c|c|c}
\hline S. No. & Conc \% (v/v) & $-\mathrm{Ea}(\mathrm{KJ}$ mol-1) & $-\Delta$ Hads (KJ mol-1) & $-\Delta$ Sads (J mol-1) \\
\hline 1. & Blank & 51.87 & 49.23 & 69.89 \\
\hline 2. & 0.006 & 52.19 & 49.55 & 81.99 \\
\hline 3. & 0.018 & 57.44 & 54.80 & 68.48 \\
\hline 4. & 0.030 & 69.70 & 67.06 & 32.91 \\
\hline 5. & 0.040 & 70.27 & 67.64 & 32.11 \\
\hline
\end{tabular}

Transition state plot (Fig.-4) of $\log (C R / T)$ versus $1 / T$ gave straight lines, $\Delta H$ was calculated form the slope $(-\Delta H \operatorname{ads} / 2.303 R)$ and $\Delta S$ was found from the intercept $[\log (R / N h)+(\Delta \operatorname{Sads} / 2.303 R)]$ and are listed 
in Table-4. Negative $\Delta$ Hads indicates that the corrosion reaction in the presence of the inhibitor is exothermic. ${ }^{14}$ Negative $\Delta \mathrm{S}^{*}$ values for inhibitor $\mathrm{H}_{3} \mathrm{PO}_{4}$ solution, showed that the inhibitor molecules moves freely in the bulk solution and the inhibitor molecules adsorbs in an orderly manner on the mild steel surface. This suggest that the activation complex in the rate determining step represents as association slightly than a dissolution step, meaning that a decrease in disordering takes place on going from reactants to the activated complex. ${ }^{15}$

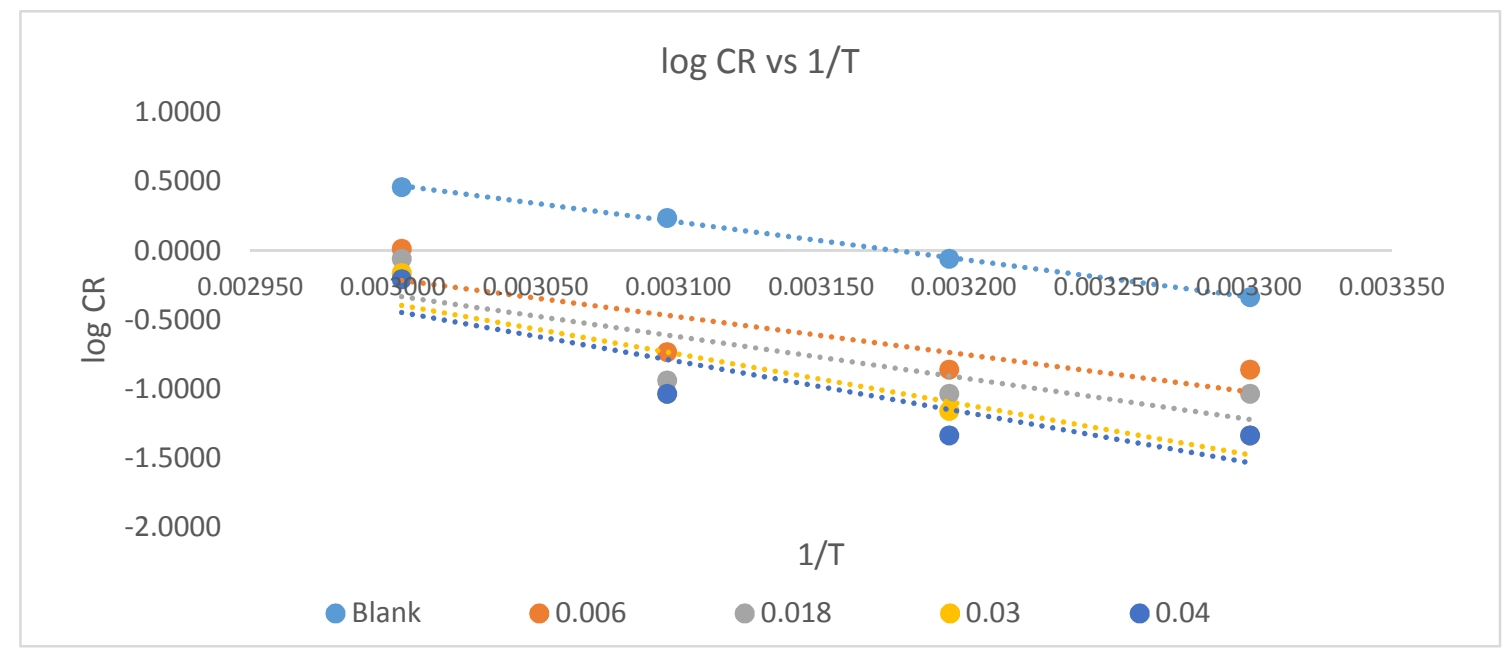

Fig.-3: Arrhenius plot

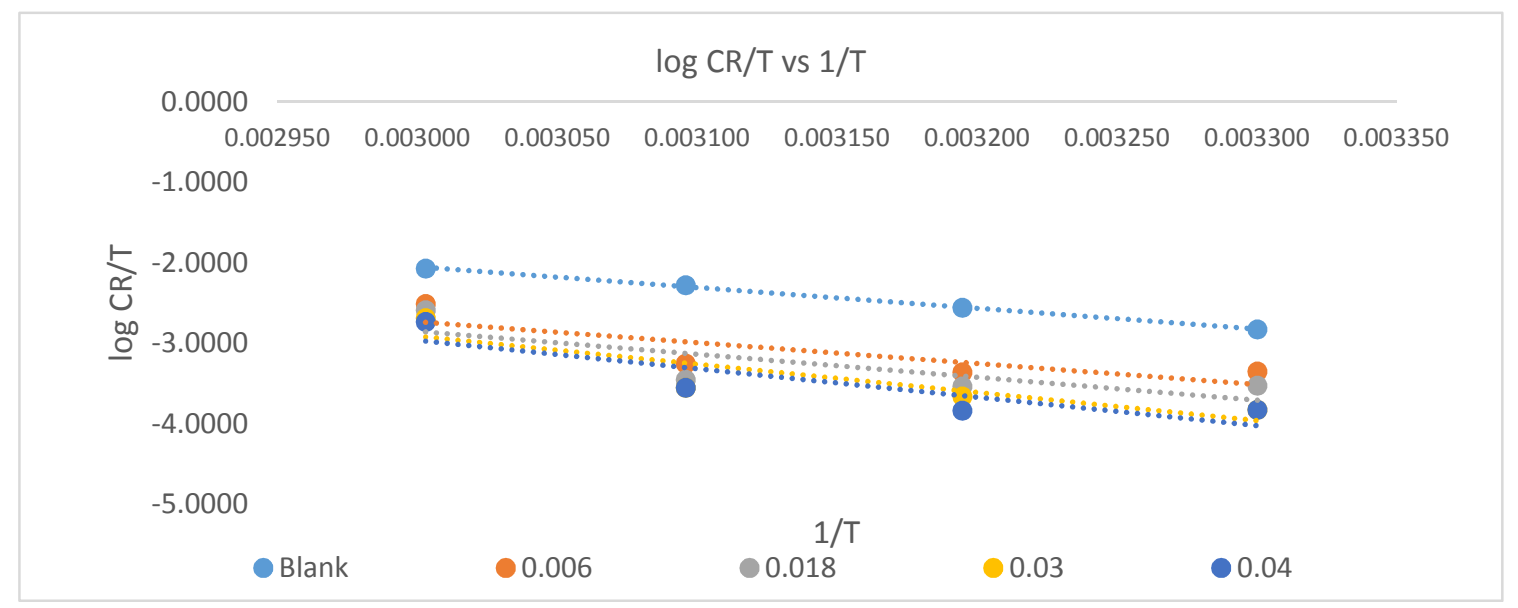

\section{Thermodynamic parameters}

Fig.-4: Transition state plot

Mechanism of corrosion inhibition was clearly indicated by the thermodynamic parameters for the adsorption of inhibitor molecules.

$\Delta \mathrm{Gads}$, as given by the following equation:

$\Delta \mathrm{Gads}=-2.303 \mathrm{RT} \log (55.5 \mathrm{~K})$

The equilibrium adsorption constant and free energy $\left(\Delta \mathrm{G}_{\text {ads }}\right)$ were obtained from these isotherms and listed in Table-5. The values are negative and lower than the threshold value of $-40 \mathrm{KJ} / \mathrm{mol}$ which is indicative for chemisorption, and hence the inhibitor molecule get adsorbed on the mild steel surface is spontaneous and the mode of inhibition follows physical adsorption. ${ }^{16-18}$ 
Table-5: Values of free energy changes for the corrosion on mild steel in $1 \mathrm{M}_{3} \mathrm{PO}_{4}$ at various temperatures.

\begin{tabular}{c|c|c|c|c|c}
\hline \multirow{2}{*}{ S. No. } & \multirow{2}{*}{ Conc. $(\% \mathrm{v} / \mathrm{v})$} & \multicolumn{4}{|c}{$-\Delta \mathrm{G}_{\text {ads }}(\mathrm{KJ} / \mathrm{mole})$} \\
\cline { 3 - 6 } & & $303 \mathrm{~K}$ & $313 \mathrm{~K}$ & $323 \mathrm{~K}$ & $333 \mathrm{~K}$ \\
\hline 1. & 0.006 & 25.120 & 28.101 & 30.210 & 26.922 \\
\hline 2. & 0.018 & 23.710 & 26.454 & 28.640 & 24.575 \\
\hline 3. & 0.030 & 24.466 & 25.949 & 27.905 & 24.054 \\
\hline 4. & 0.040 & 23.741 & 26.329 & 27.132 & 23.633 \\
\hline
\end{tabular}

\section{Potentiodynamic polarization measurements}

Potentiodynamic polarization curve and potentiodynamic polarization parameters of mild steel immersed in $1 \mathrm{M} \mathrm{H}_{3} \mathrm{PO}_{4}$ in the absence and presence of different inhibitor concentrations are given in Fig. -5 and Table-5. Important corrosion parameters like corrosion current, corrosion potential, Tafel slopes $\left(\beta_{\mathrm{a}} \& \beta_{\mathrm{c}}\right)$ were evaluated by potentiodynamic polarization measurements. It is evident from the Table- 6 that the decreased $\mathrm{I}_{\text {corr }}$ values with increased inhibitor concentration are the direct evidence for the corrosion protection of mild steel by the inhibitor. It is further observed from the $\mathrm{E}_{\text {corr }}$ values that they slightly move towards positive side and the Tafel slope values $\left(\beta_{\mathrm{a}} \& \beta_{\mathrm{c}}\right)$ specifies that the inhibitor prevents both anodic and cathodic corrosion reactions and hence the human hair extract is classified as mixed type inhibitor. For all inhibitor concentrations, $\beta \mathrm{a}$ is lesser than $\beta \mathrm{c}$ indicating that yet the inhibition is under mixed control, the effect of the inhibitor on the cathodic polarization is distinct than on the anodic polarization. ${ }^{19}$ was calculated using the Stern-Geary Equation- 6 was used to calculate the polarization resistance $\left(R_{p}\right)$ from Tafel extrapolation method. The inhibition efficiency was determined by the formula (1) and (2) and are tabulated in Table-6.

Icorr $=\frac{\beta a \beta c}{2.303(\beta a+\beta c)} \frac{1}{R p}$

I. E. $\%=\frac{\mathrm{I}^{\mathrm{o}} \text { corr }-\mathrm{I} \text { color }}{\mathrm{I}^{\mathrm{O}} \text { corr }} \times 100$

$\mathrm{IE}(\%)=\frac{\mathrm{Rp}(\mathrm{inh})-\mathrm{Rp}(\text { Blank })}{\mathrm{Rp}(\mathrm{inh})} \times 100$

Where $\mathrm{I}_{\text {corr }}{ }^{\mathrm{a}}$ is the corrosion current density measured for MS in $1 \mathrm{M} \mathrm{H}_{3} \mathrm{PO}_{4}$ without inhibitor and $\mathrm{I}_{\text {corr }}$ is the corrosion current density containing plant extracts, respectively. It is also found that the $\mathrm{R}_{\mathrm{p}}$ values increases on increasing the concentration. ${ }^{20-21}$

Table-6: Kinetic parameters of MS in $1 \mathrm{M} \mathrm{H}_{3} \mathrm{PO}_{4}$ for various concentrations of the inhibitor

\begin{tabular}{c|c|c|c|c|c|c|c|c}
\hline S. No. & $\begin{array}{c}\text { Inhibitor } \\
\text { Conc. } \\
\end{array}$ & $(\% \mathrm{v} / \mathrm{v})$ & $-\mathrm{E}_{\text {corr }}(\mathrm{mV})$ & \multirow{2}{*}{$\begin{array}{c}\mathrm{I}_{\text {corr }} \\
(\mu \mathrm{A})\end{array}$} & $\begin{array}{c}\beta_{\mathrm{a}} \\
(\mathrm{mV} / \mathrm{dec})\end{array}$ & $\begin{array}{c}\beta_{\mathrm{c}} \\
(\mathrm{mV} / \mathrm{dec})\end{array}$ & $\begin{array}{c}\mathrm{R}_{\mathrm{p}} \\
\left(\Omega \mathrm{cm}^{2}\right)\end{array}$ & \multicolumn{2}{|c}{$\mathrm{IE}(\%)$} \\
\hline 1. & Blank & 884.173 & 822.449 & 111 & 174.4 & 358.1068 & $* *$ & $\mathrm{I}_{\text {corr }}$ \\
\hline 2. & 0.006 & 888.569 & 267.125 & 108.6 & 136.1 & 981.8508 & 67.52 & 63.53 \\
\hline 3. & 0.018 & 878.94 & 258.091 & 93.3 & 108.3 & 843.2431 & 68.62 & 57.53 \\
\hline 4. & 0.03 & 877.51 & 189.426 & 92.5 & 122.5 & 1208.108 & 76.97 & 70.36 \\
\hline 5. & 0.04 & 868.035 & 157.097 & 107.2 & 133.7 & 1644.476 & 80.90 & 78.22 \\
\hline
\end{tabular}

\section{Electrochemical Impedance Measurements}

Corrosion tendency of mild steel in acidic media in the without and with the alkali extract of human hair was studied by means of Electrochemical Impedance Spectroscopy. Nyquist plot of MS in uninhibited and inhibited $1 \mathrm{M} \mathrm{H}_{3} \mathrm{PO}_{4}$ is shown in Fig.-6 and the impedance parameters like $\mathrm{R}_{\mathrm{ct}}$ (Charge transfer resistance), $\mathrm{C}_{\mathrm{dl}}$ (Double layer capacitance) and their I.E. \% were given in Table-7. The Nyquist diagram has shown 
RASĀYAN J. Chem.

Vol. 10 | No. 4 |1462-1471 | October - December | 2017

considerable change with the addition of the inhibitor, that is as these circle diameter increases on increased inhibitor concentration, which is indicative of the controlled corrosion process. $R_{c t}$ the charge transfer resistance value increases by increasing the concentration of the inhibitor which caused the inhibition efficiency to increase. The double layer capacitance $\mathrm{C}_{\mathrm{dl}}$ value found to decrease with increase in inhibitor concentration which indicated the adsorption of the inhibitor on the surface of the mild steel surface. ${ }^{22-25}$

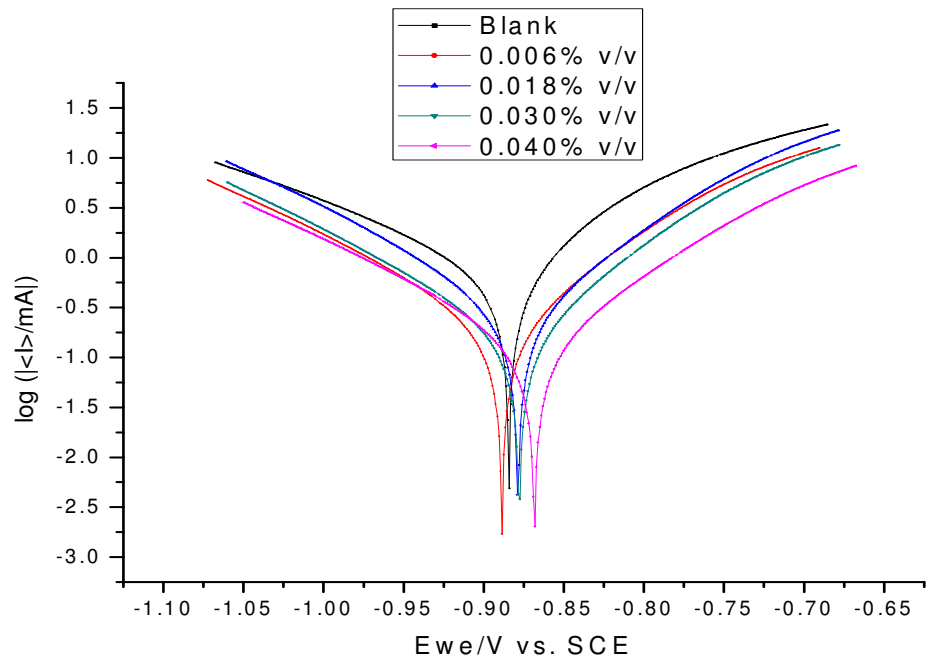

Fig.-5: Tafel plot of $\mathrm{MS}$ in $1 \mathrm{M} \mathrm{H}_{3} \mathrm{PO}_{4}$ containing various concentrations of the inhibitor

Table-7: Impedance parameters for mild steel in $1 \mathrm{M} \mathrm{H}_{3} \mathrm{PO}_{4}$ in the absence and presence of various concentrations of inhibitors

\begin{tabular}{c|c|c|c|c|c}
\hline \multirow{2}{*}{ S. No. } & \multirow{2}{*}{ Conc. $(\% \mathrm{v} / \mathrm{v})$} & \multirow{2}{*}{$\mathrm{R}_{\mathrm{ct}} \mathrm{Ohm}$} & \multirow{2}{*}{$\mathrm{C}_{\mathrm{dl}} \mathrm{F}$} & \multicolumn{2}{|c}{$\mathrm{IE} \%$} \\
\cline { 5 - 6 } & & 19.294 & $0.126 * 10^{\wedge}-3$ & $\mathrm{C}_{\mathrm{dl}}$ & $\mathrm{R}_{\mathrm{ct}}$ \\
\hline 1. & Blank & $1 *$ & $* *$ \\
\hline 2. & 0.006 & 60.15 & $50.41 * 10^{\wedge}-6$ & 59.93 & 67.92 \\
\hline 3. & 0.018 & 64.062 & $45.12 * 10^{\wedge}-6$ & 64.13 & 69.88 \\
\hline 4. & 0.03 & 95.129 & $37.3 * 10^{\wedge}-6$ & 70.35 & 79.72 \\
\hline 5. & 0.04 & 134.362 & $30.68 * 10^{\wedge}-6$ & 75.61 & 85.64 \\
\hline
\end{tabular}

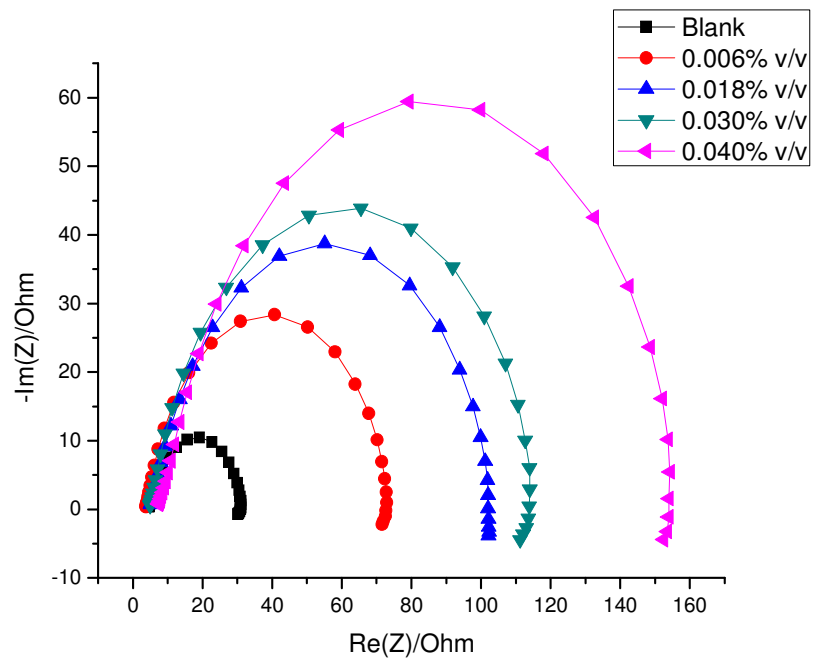

Fig.-6: Nyquist plot of mild steel in $1 \mathrm{M} \mathrm{H}_{3} \mathrm{PO}_{4}$ in the without and with various concentration of inhibitors 


\section{Surface morphology by Scanning electron microscope (SEM)}

Fig.-7a and $7 \mathrm{~b}$ show the corrosion morphology of MS immersed in $1 \mathrm{M} \mathrm{H}_{3} \mathrm{PO}_{4}$ containing inhibitor extract after immersion of 2 hours. The Phosphoric acid attacks the mild steel surface in Fig.-7a causing an uneven surface, whereas in the presence of inhibitor more even surface is shown in Fig.-7b. ${ }^{26}$



(a)

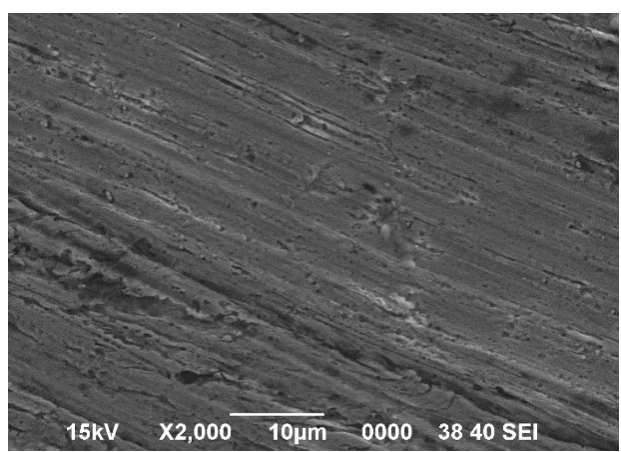

(b)

Fig.-7: Corrosion surface morphology $\left(1 \mathrm{M} \mathrm{H}_{3} \mathrm{PO}_{4}\right)$

\section{CONCLUSION}

The inhibitor (Human black hair) sample used for this present study acts as a very good corrosion inhibitor in $1 \mathrm{M}$ phosphoric acid medium. The I.E. (\%) increases on increasing the concentration of the inhibitor. Adsorption of the inhibitor on the mild steel surface in acid medium followed Langmuir and Temkin adsorption isotherm. Free energy values evidenced the corrosion process as spontaneous and the mechanism follows physisorption. The data obtained from the polarization studies proved it be a mixed type inhibitor. SEM micrographs confirmed the formation of protecting layer over the surface of the mild steel.

\section{REFERENCE}

1. M.S. Al-Otaibi, A.M. Al-Mayouf, M. Khan, A.A. Mousa, S.A. Al-Mazroa and H.Z. AlKhathlan, Arabian Journal of Chemistry, 7, 340(2014)

2. G. Sigircik, T. Tüken and M. Erbil, Corrosion Science, 102, 437(2016)

3. A. Sharmila, A. Angelin Prema and P. Arockia Sahayaraj, Rasayan Journal of Chemistry, 3(1) 74(2010)

4. R.J. Block, D. Boiling, The amino acid composition of proteins and foods, 2nd; Charles C. Thomas, Springfield, Ill., (1951)

5. R.J.Gold, C. R. Scriver, Clin. Chim. Acta, 33, 465(1971)

6. Ari L. Horvath, The Scientific Worlds Journal, 9, 255(2009)

7. S. S. Shivakumar and K. N. Mohana, International Journal of Corrosion, Volume 2013, Article ID 543204, 13 page

8. K. Anbarasi and V. G. Vasudha, Chem. Sci. Rev. Lett., 3(9), 45(2014)

9. N.O. Eddy, S.A, Odoemelam and A.O. Odiongenyi, Advances in Natural and Applied Sciences, 2(1), $35(2008)$

10. E.E. Oguzie, Y. Li, F.H. Wang, Journal of Colloid and Interface Science, 310, 90(2007).

11. N.O. Eddy, S.A, Odoemelam and A.O. Odiongenyi, Advances in Natural and Applied Sciences, 2(1), 35(2008)

12. E. Ebenso, Bull. of Electrochem., 19, 209 (2003)

13. N. O. Eddy and E. E. Ebenso, African Journal of Pure and Applied Chemistry, 2(6), 46(2008)

14. R. Saratha and R. Meenakshi, Der Pharma Chemica, 2(1), 287(2010)

15. N.O. Obi-Egbedi and I.B. Obot, Arabian Journal of Chemistry, 5, 121(2012)

16. M. Bouklah and B. Hammouti, Portugaliae Electrochimica Acta, 24, 457(2006)

17. Zhihua Tao, Shengtao Zhang, Weihua Li and Baorong Hou, Ind. Eng. Chem. Res., 49(6), 2593(2010)

18. N. O. Eddy and P. A. P. Mamza, Portugaliae Electrochimica Acta, 27(4), 443(2009)

19. R. Saratha, S.V.Priya and P.Thilagavathy, E-Journal of Chemistry, 6(3), 785(2009) 
RASĀYAN $J$. Chem.

Vol. 10 | No. 4 |1462-1471 | October - December | 2017

20. M.S. Al-Otaibi, A.M. Al-Mayouf, M. Khan, A.A. Mousa, S.A. Al-Mazroa and H.Z. Alkhathlan, Arabian Journal of Chemistry, 7, 340(2014)

21. M. Shyamala and A. Arulanantham, J. Mater. Sci. Technol., 25(5), 633(2009)

22. S. Rajendran, J. Jeyasundari, P. Usha, J. A. Selvi, B. Narayanasamy,2 A. P. P. Regis and P. Rengan, Portugaliae Electrochimica Acta, 27(2), 153(2009)

23. T. Deepa and C. Thangavelu, Rasayan Journal of Chemistry, 10(2), 584(2017)

24. Rathika Govindasamy and Swetha Ayappan, J. Chil. Chem. Soc., 60(1), 2786(2015)

[RJC-1947/2017] 